\title{
Forearm replantation after traumatic complete amputation
}

\author{
Naoki Yoshida, Yoshihiko Tsuchida
}

Department of Orthopedic Trauma Surgery, Shonan Kamakura General Hospital, Kanagawa, Japan

\section{Correspondence to} Dr Naoki Yoshida, n_yoshida@shonankamakura. or.jp

Accepted 3 November 2018

\section{DESCRIPTION}

A 67-year-old man presented to the emergency department with right forearm complete amputation. His right arm had been caught between heavy machinery during working. He was transported to our hospital by helicopter from the injury scene, which was approximately $70 \mathrm{~km}$ away. He had no other injuries, so he was taken to the operating room immediately. The time from injury to the operating room was 1 hour $54 \mathrm{~min}$. The wound was crushed and had many metal fragments (figure 1). After debridement, osteosynthesis and vascular anastomosis were performed. Subsequently, nervous anastomosis was performed, muscles were readapted and tendons were sutured. We used negative pressure wound therapy (NPWT) for skin and soft tissue deficits at the end of the operation. On postoperative day 4 , we reconstructed skin and soft tissue by using the free latissimus dorsi muscle flap. We then covered the remaining raw surface area with a split-thickness skin graft. After confirming that the flap and skin graft succeeded, we removed the NPWT device, which had been worn for 19 days. The postoperative course was uneventful. Because the NPWT device had been worn for 19 days, the range of motion (ROM) of his elbow was initially limited. However, the ROM gradually improved because of good effort during rehabilitation. At postoperative 1 month, the patient was transferred to a rehabilitation hospital (figure 2). At postoperative 10 months, the disabilities of the arm, shoulder and hand score were 67. Despite

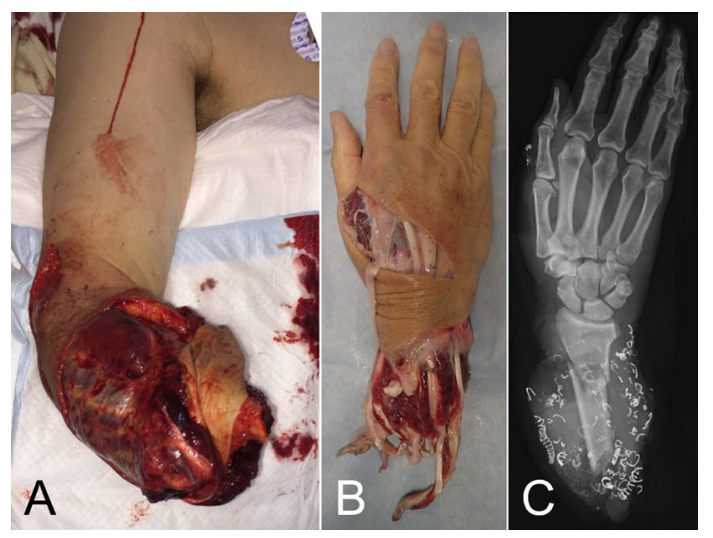

Figure 1 (A, B) Clinical photograph showing the right forearm complete amputation. (C) Radiograph showing many metal fragments. The ulna bone is missing.

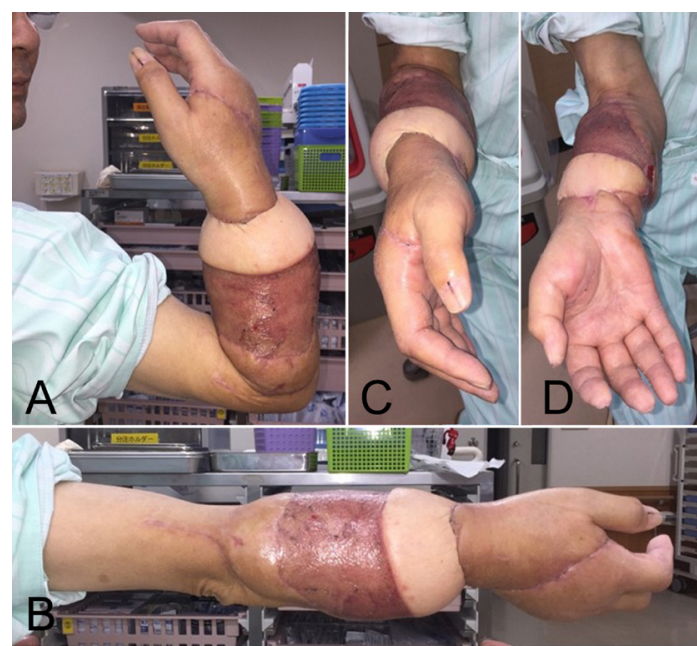

Figure $2(A, B)$ Clinical photograph showing the successful replantation. Range of motion of the right elbow joint was $0-90-110^{\circ}$. (C, D) Clinical photograph showing pronation/supination of the right hand was $10-0-75^{\circ}$.

the poor functional ability, the patient was quite satisfied and appreciative.

Limb amputation causes not only loss of physical integrity but also affects an individual's mental and social well-being and is a significant problem, especially for younger people and the working population. ${ }^{1}$ The success rate for replantation after major upper extremity amputation is reported in $77 \%-93 \% .^{2}$ The success rate depends considerably on the grade of damage. The long-term subjective functionality of replanted upper extremities is satisfactory for patients, and patients appear to have adapted to impaired function, even if their functionality is reduced. Despite the significant progress of modern prosthetic devices, high rejection rates are still observed in most traumatic amputation patients. Hence, arm replantation is still believed to be superior to an amputation stump fitted with an appropriate prosthesis. ${ }^{3}$

\section{Learning points}

- Limb amputation has a profound impact on patient's quality of life and poses a burden on social economy.

- The long-term subjective functionality of replanted upper extremities is satisfactory for patients. 
Contributors The patient's care was overseen by NY, YT. YT provided assistance with the drafting of the manuscript. All authors approved the manuscript prior to submission.

Funding The authors have not declared a specific grant for this research from any funding agency in the public, commercial or not-for-profit sectors.

Competing interests None declared.

Patient consent Obtained.

Provenance and peer review Not commissioned; externally peer reviewed.

\section{REFERENCES}

1 Nwosu C, Babalola MO, Ibrahim MH, et al. Major limb amputations in a tertiary hospital in North Western Nigeria. Afr Health Sci 2017;17:508-12.

2 Mattiassich G, Rittenschober F, Dorninger $L$, et al. Long-term outcome following upper extremity replantation after major traumatic amputation. BMC Musculoskelet Disord 2017:18:77.

3 Otto IA, Kon M, Schuurman AH, et al. Replantation versus prosthetic fitting in traumatic arm amputations: a systematic review. PLoS One 2015;10:e0137729.

Copyright 2018 BMJ Publishing Group. All rights reserved. For permission to reuse any of this content visit https://www.bmj.com/company/products-services/rights-and-licensing/permissions/

BMJ Case Report Fellows may re-use this article for personal use and teaching without any further permission.

Become a Fellow of BMJ Case Reports today and you can:

- Submit as many cases as you like

- Enjoy fast sympathetic peer review and rapid publication of accepted articles

- Access all the published articles

- Re-use any of the published material for personal use and teaching without further permission

For information on Institutional Fellowships contact consortiasales@bmjgroup.com

Visit casereports.bmj.com for more articles like this and to become a Fellow 